\title{
Yrkesfaglig lærerkompetanse i brede utdanningsprogram
}

\author{
Jorunn Dahlback, Hanne Berg Olstad, Ann Lisa Sylte og Anne-Catrine Wolden \\ (likeverdige forfattere)
}

\section{Abstrakt}

Målet med denne artikkelen er å belyse kompetanseområder en yrkesfaglærer trenger for å undervise i brede yrkesfaglige utdanningsprogram med tidlig yrkesspesialisering i videregående skole i Norge. Det er bred enighet om de generelle overordnede kompetanseområdene en lærer trenger, men forsket lite på hvilken kompetanse som konkret kreves for å undervise i brede utdanningsprogram. Med ny tilbudsstruktur som innføres i 2020, stilles det tydeligere krav om tidlig yrkesspesialisering fra første året i videregående skole. Hensikten med studien var også å undersøke hvilke implikasjoner endrede krav til lærerkompetanse gir for innholdet i yrkesfaglærerutdanningen. Forskningsspørsmålene handlet om hvilken kompetanse studentene viste i sin pedagogiske praksis, og hvordan yrkesfaglærerutdanningen kan og bør styrkes. Empirigrunnlaget er hovedsakelig basert på kvalitative undersøkelser med metoder som spørreundersøkelser, intervju og skriftlig materiell fra dialogkonferanser og evalueringer med noen kvantitative elementer fra perioden 2014 - 2017. Resultatene viser at studenter og yrkesfaglærere trenger mer opplæring i praktiske ferdigheter tilpasset de ulike yrkene som inngår i brede utdanningsprogram. Behovet for helhetlig lærerkompetanse ble her fremhevet, mens den faglige substansen som inngår i felleselementene i brede utdanningsprogram, må styrkes for å ivareta tidlig yrkesspesialisering. Likedan må koherensen mellom pedagogikk og yrkesdidaktikk, og praksisfeltet styrkes ytterligere. 
Emneord: koherens, profesjonsretting, yrkesspesialisering, helhetlig lærerkompetanse, praktiske ferdigheterAbstrakt (not applicable for articles in English language) 


\section{Introduksjon}

Tidlig yrkesspesialisering er et hovedfokus i den nye skolereformen som kommer i norsk yrkesfagopplæring i 2020 (Utdanningsdirektoratet, 2018). Læreplanverket i Kunnskapsløftet (Kunnskapsdepartementet, 2006) er blant annet kritisert for svak yrkesretting og til dels manglende yrkesrelevans (Aspøy, Skinnarland \& Tønder, 2017; Kunnskapsdepartementet, 2016; Sylte, 2017; Vibe, Frøseth, Hovdhauen \& Markussen, 2012). Utdanningsprogrammet Design og håndverk $(\operatorname{Vg} 1 \mathrm{DH})$ som leder til 52 ulike yrkesfag, blir i den nye strukturen delt i to (Utdanningsdirektoratet, 2018). Det ene leder til seks yrkesfag, deriblant frisør, blomsterdekoratør- og interiørkonsulent. De resterende yrkene, som er definert som tradisjonshåndverk, er samlet i det andre. Begge utdanningsløpene innebefatter selv om de blir smalere, fremdeles yrker med svært ulike arbeidsprosesser og materialer. Arbeidet med revidering av nye læreplaner på Vg1 startet høsten 2018.

Hovedmodellen i dagens norske yrkesfagopplæring er to år i skole etterfulgt av to års læretid i bedrift, med tilbud om åtte brede utdanningsprogrammer (Kunnskapsdepartementet, 2006). Denne artikkelen er basert på empiri fra $\mathrm{Vg} 1 \mathrm{DH}$, som i dag rekrutterer til svært ulike yrkesfag som frisør, båtbygger og gullsmed (Utdanningsdirektoratet, 2006). Disse yrkene har svært varierte produksjonsprosesser og bruker ulike materialer, noe som gir store utfordringer for hva en yrkesfaglærer må ha av opparbeidet kompetanse utover eget fagbrevområde. Ifølge en evaluering foretatt av NIFU (Høst, Reegård, Reiling, Skålholt \& Tønder, 2015), opplever arbeidsgiverne at nivået på den yrkesfaglige kompetansen etter to år i skole er svekket, mens lærerne sier at de er usikre på hva som er formålet med utdanningsprogrammet DH (Utdanningsdirektoratet, 2016).

Lærerutdannere og lærerstudenter ved 3-årig yrkesfaglærerutdanning (YFL) erfarte til dels manglende koherens mellom YFLs innhold knyttet til lærerkompetanse, og praksisfeltets utøvende praksis (Dahlback, Olstad, Sylte \&Wolden, 2018). I innholdet vektlegges det en helhetlig lærerkompetanse som innebærer yrkesfaglig bedde, dybde, yrkesdidaktikk og pedagogikk. Rammeplanene for Yrkesfaglærerutdanningen (YFL) (Kunnskapsdepartementet, 2013) og programplanene ved OsloMet - storbyuniversitetet (OsloMet) (Høgskolen i Oslo og Akershus, 2014) har et sterkt fokus på profesjonsretting av innholdet i opplæringen. 
Nyere forskning viser at relevansproblematikk, som lite profesjonsretting og svak koherens (sammenheng) mellom profesjonsutdanning og praksisfeltet, er en utfordring i dagens lærerutdanninger (Canrinus, Bergem, Klette \& Hammerness, 2015; Heggen \& Terum, 2013; Hiim, 2015; Sylte, 2018). Forskning peker også på at det er manglende koherens mellom YFL og mange praksislæreres tolking av hvilken lærerkompetanse som fremmer relevant yrkesopplæring i brede utdanningsprogram (Dahlback, Hansen, Haaland \& Vagle 2015; Dahlback, Haaland \& Vagle, 2016).

På bakgrunn av relevansproblematikken i lærerutdanningen og ny tilbudsstruktur er problemstillingen: Hvilke implikasjoner gir nye krav om tidlig yrkesspesialisering for innholdet i yrkesfaglærerutdanningen? Forskningsspørsmålene var følgende: a) Hvilken lærerkompetanse viste studentene i pedagogiske praksis? b) Hvilken lærerkompetanse er det behov for i brede yrkesfaglige utdanningsprogram med vekt på tidligere yrkesspesialisering? Hensikten var å utvikle ny kunnskap om relevant lærerkompetanse for undervisning i brede utdanningsprogrammer med vekt på tidlig yrkesspesialisering. Dette for å imøtekomme samfunnets, praksisfeltets og studentenes behov for kompetanse, som vektlegges i styringsdokumenter (Kunnskapsdepartementet, 2006, 2016, 2017). I yrkesopplæringen innebærer dette målet en mer konsistent opplæring fra $\mathrm{Vg} 1$ til Vg3, med progresjon fram til lærefag og yrker (Kunnskapsdepartementet, 2013, 2016).

\section{Tidligere forskning}

Jørgensen (2018) trekker opp fire utfordringer i dagens yrkesutdanninger i Norden: oppdatert kunnskap i yrker som er i stadig utvikling, overgangen fra yrkesfag til høyere utdanning, lav status og høy grad av drop out, samt sosial inkludering av søkere som ikke nødvendigvis er modne for å ta en utdanning på videregående nivå. Disse utfordringene har alle direkte eller indirekte innvirkning på en yrkesfaglærers kompetansebehov.

Word Economic Forum (2018) la i sin rapport fram de 10 viktigste kompetanseområdene næringslivet trengte i 2015, sammenlignet med de 10 viktigste kompetansebehovene de mente ville bli etterspurt i 2020. Kompetanseområdene var stort sett sammenfallende, men rekkefølgen ble endret og noen nye kompetanseområder ble tilføyd. Kompleks problemløsning ble høyest rangert i 2015 og likedan for 2020. I tillegg ble kritisk tenkning, 
kreativitet, personlig ledelse, koordinering og samarbeid, emosjonell intelligens, dømmekraft og beslutningstaking, serviceorientering, forhandlingsevne, og kognitiv fleksibilitet, fremhevet som de mest etterspurte kompetansene i 2020. Mange av disse kompetansene er sammenfallende med Wagners (2008) internasjonale forskning der han har unders $\varnothing \mathrm{kt} \mathrm{hvilken}$ kompetanse gründere og næringslivstopper ser etter når de skal ansette nye medarbeidere. Han kom fram til syv kompetanseområder: Problemløsning og kritisk tenkning, samarbeid gjennom nettverk og ledelse, tilpasningsevne, initiativ og entreprenørskap, god skriftlig og muntlig kommunikasjon, evnen til å analysere, nysgjerrighet og fantasi. Samtidig problematiserer Deichman-Sørensen (2015) at det kan gå utover de spesifikke ferdighetene og teknikkene man trenger for å kunne utøve et spesifikt yrke, hvis opplæringen blir så generell at den til enhver tid kun skal tilfredsstille endringsbehovene i samfunnet. Sennet (2008) synliggjør også at fleksibilitet er nødvendig for de fleste yrker, men at det kan gi en overfladisk kunnskap og et arbeidsliv uten substans. Det er disse dilemmaene mellom tverrfaglig pedagogisk og didaktisk kompetanse, og praktisk faglig dybde- og breddekompetanse i YFL denne forskningen setter fokus på.

Wheelahn og Woodie (2010) har i en australsk studie sett på yrkesfaglærerens kompetanse og hvordan de underviser i praktiske fag. Deres resultater viser at undervisning og opplæring i yrkesfagene er kompleks og at lærerne må ha en høy grad av autonomi. Det fremheves at lærernes yrkesfaglige kompetanse handler om hvordan de legger til rette for læring i praktiske yrkesfag. Lærernes kompetanse knyttes til problemløsing i komplekse situasjoner. Skulberg og Sund (2011) sin forskningsrapport beskriver yrkesfaglærerens kompetanse i fem kjerneområder; solid faglig kompetanse, didaktisk kompetanse, sosialkompetanse, endringsog utviklingskompetanse, og yrkesetisk kompetanse som kjernen i lærernes profesjonskunnskap. I tillegg skal yrkesfaglærerne ha kompetanse som innebærer å planlegge, gjennomføre og vurdere undervisning i tråd med yrkenes egenart, elevenes forutsetninger og interesser, arbeidslivet og samfunnets kvalifikasjonskrav og lov- og læreplanverk (Kunnskapsdepartementet, 2013). Denne forskningen er i tråd med intensjonen i ramme- og programplanen for YFL.

Både Skulberg og Sunds (2011), Wheelahn og Woodies (2010) og Wagners (2008) forskning kan ses i sammenheng med Dahlback, Hansen, Haaland og Syltes (2011) og Syltes (2017) 
forskning, som synliggjør behovet for en helhetlig lærer- og yrkeskompetanse. Helhetlig yrkeskompetanse innebærer ulike komponenter som sosial-, fag-, og nøkkelkompetanse knyttet til praktiske ferdigheter. Nøkkelkompetanse kan ofte være taus kunnskap som for eksempel ansvarlighet, kreativitet, evnen til analytisk, innovativ og kritisk tenkning og problemløsning. Forskningen poengterer at når studenter og elever ble bevisstgjorte på nøkkelkompetansen som inngår i helhetlig yrkeskompetanse, $\varnothing$ kte både motivasjonen og læringsutbyttet (Sylte, 2014, 2017).

Nasjonal forskning peker på utfordringer knyttet til relevant yrkesopplæring for elever som går på brede utdanningsløp i Vg1 i Norge. Skolene og lærerne har ulike måter å organisere opplæringen på, noe som fordrer ulik lærerkompetanse i brede Vg1 (Dahlback et al., 2018; Hansen \& Haaland, 2015). Dermed var det interessant å unders $\varnothing$ ke om denne organiseringen kunne ha betydning for hvilken lærerkompetanse YFL-studentene fikk mulighet til å vise i sin pedagogiske praksis, og hvilken lærerkompetanse praksislærerne så behov for i Vg1. Samtidig viser annen forskning at lærerens kompetanse må utvides med kunnskap om yrkesdifferensiering (Dahlback et al., 2015; Bødtker-Lund, Hansen, Haaland \& Vagle, 2017). Yrkesdifferensiert opplæring er basert på elevenes yrkesinteresser og videre utdanningsplaner med et yrkesdidaktisk fokus (Hansen \& Haaland, 2015). Bødtker-Lund et al. (2017) konkluderer med at læreren og lærerteamets fagkompetanse har stor betydning for relevansen i yrkesfaglig opplæring. De peker på at flere skoler har lærerteam med smal fagkompetanse, noe som vanskeligjør en yrkesfaglig opplæring i tråd med elevenes yrkesinteresser i brede Vg1-programmer.

Både internasjonal og norsk forskning peker på behov for å tydeliggjøre yrkes- og profesjonsutdanningenes yrkesrelevans der både yrkesfaglærere og lærerutdannere må styrke undervisningen og forankringen til arbeidslivet for å øke utdanningskvaliteten (Billett, 2014; Hiim, 2017; Jørgensen, 2018). Aspøy, Skinnarland og Tønder (2017) belyser yrkesfaglærernes kompetanse med grunnlag i rektorer, skoleeiere, yrkesfaglærere og opplæringskontor som informanter. Rektorene trekker fram lærerens fagkompetanse og evnen til å holde seg oppdatert på utviklingen i arbeid og næringsliv som essensielt. De mener at yrkesfaglærerne må ha dybdekunnskap og spisskompetanse i eget fagområde samt yrkesfaglig breddekompetanse for lærere som jobber på brede utdanningsprogram på Vg1. I tillegg til den pedagogiske kompetansen og yrkeskompetansen trekker lærerne fram behovet 
for relasjonskompetanse og samhandlingskompetanse. Opplæringskontorene mener at yrkesfaglærerne i tillegg til formidlingskompetanse og fagkompetanse må ha god kjennskap til de yrkesfagene og arbeidsmarkedet de utdanner for (Aspøy et. al., 2017).

En stor internasjonal studie gjorde forsøk i lærerutdanninger i fem land (Canrinus et al., 2015). Fors $\varnothing$ kene handlet om koherens mellom undervisningen på utdanningsinstitusjonen og pedagogisk praksis i skolen ved å knytte teori og praksis sammen. Forskerne framhevet her viktigheten av koherens mellom lærerutdanningene og praksisfeltet. Jørgensen (2018) poengterer også betydningen av et tettere samarbeid mellom profesjonsutdanningene, skole og arbeidsliv. Dermed så vi det som viktig å studere om behovet for lærerkompetanse med vekt på tidligere yrkesspesialisering var koherent med YFLs innhold.

Tidligere forskning på lærerkompetanse viser stor enighet om de generelle overordnede kompetanseområdene som vektlegges i ramme- og programplanen (Aspøy et al., 2017). Samtidig viser forskningen behov for å utvikle den pedagogiske praksisen i både yrkesopplæringen og YFL (Dahl, Bruland, Mordal \& Aaslid, 2012; Hiim, 2013; Landro \& Utvær, 2010). Det finnes imidlertid lite forskning som sier noe om hvilken konkret lærerkompetanse som kreves for å undervise i yrkesopplæringens brede utdanningsprogram med vekt på tidlig yrkesspesialisering, noe denne forskningen vil bidra med.

\section{Lærerkompetanse i brede yrkesfaglige utdanningsprogram}

Lærerkompetanse defineres som summen av lærernes praktiske ferdigheter, kunnskaper, evne til refleksjon og personlige kvaliteter (Kunnskapsdepartementet, 2009). Kompetansebegrepet defineres på ulike måter som for eksempel i føringen til ny tilbudsstruktur 2020:

«Kompetanse er å skaffe og anvende kunnskap og ferdigheter til å mestre utfordringer og løse problemer i kjente og ukjente sammenhenger og situasjoner. Kompetanse betyr forståelse og evne til refleksjon og kritisk tenkning» (Kunnskapsdepartementet, 2016). Denne nye definisjonen samsvarer i stor grad med Wagners (2008) forskning med styrking av evne til refleksjon og kritisk tenkning. Yrkesfaglærerkompetanse innbefatter ifølge rammeplanen og programplanen for YFL, pedagogisk og didaktisk kompetanse, faglig, yrkesetisk, relasjonsog endrings- og utviklingskompetanse (Høgskole i Oslo og Akershus, 2014; 
Kunnskapsdepartementet, 2013). I rammeplanen presiseres det at de fem kompetansene integreres i hverandre og innebærer forskjellige aspekter i en helhetlig yrkesfaglig lærerkompetanse. Fellestrekkene her er fokus på koherens mellom kunnskap, ferdigheter og generell kompetanse, noe som viser behovet for en helhetlig lærerkompetanse som igjen krever en profesjonsrettet lærerutdanning (Sylte, 2017). Profesjonsretting i lærerutdanningen innebærer tett kobling mellom undervisningsfagene og pedagogikk og didaktikk (Kunnskapsdepartementet, 2009). Vi kan også se nødvendigheten av profesjonsretting og helhetlig yrkeskompetanse i tråd med Sennet (2008) sin tenkning. Yrkene er i stadig utvikling og endring, og godt fagarbeid inkluderer også evne til kreativ og selvstendig problemløsning, som en viktig kompetanse i alle yrker. Det handler om at studentene får mulighet til fleksibilitet i sin pedagogiske praksis, men at de også får tid og mulighet til å gå i dybden for å utvikle faglig substans.

\section{Yrkesfaglærerkompetanse}

Ramme- og programplanen for YFL (Kunnskapsdepartementet, 2013; Høgskole i Oslo og Akershus, 2014) kan ses i lys av et pragmatisk, praksis- og kompetansebasert læringsperspektiv (Dewey, 1916). Dette perspektivet er preget av nær koherens mellom teori og praksis, som tar utgangspunkt i yrkesoppgaven og -utøvelsen (Hiim, 2013). Det betyr at innholdet i studiet er basert på en virkelighetsnær kontekstavhengig forståelse av praksisfeltet og ikke av disiplininndelte abstrakte teorier (Hiim, 2013). Studentene har 130 dager praksis i løpet av studietiden. De har 70 dager med pedagogisk praksis i praksisskole med praksislærer, og 60 dagers yrkesfaglig praksis i ulike yrkesfag veiledet av fagutdannede yrkesutøvere i reelle arbeidssituasjoner.

Studentenes bakgrunn før opptak til YFL er fagbrev eller tilsvarende, og minimum fire års praksis i yrket. Et av målene i studiet er at studentene skal videreutvikle yrkesfaglig dybde ved å analysere kompetansebehov og endringer i eget yrkesfag. I tillegg skal studentene utvikle yrkesfaglig breddekompetanse ved å opparbeide innsikt i særtrekk og fellestrekk mellom alle yrkene som inngår i utdanningsprogrammet.

Yrkeskompetanse innebærer både en produksjonslogikk og en utviklingslogikk. Produksjonslogikken innbefatter effektivitet, rasjonelle mål, problemløsing for å finne regler og instruksjoner, konsistent og lik handling, stabilitet og sikkerhet, læring orientert mot 
foreskrevne prosedyrer og rutiner. Utviklingslogikken handler om refleksjon, kreativitet, eksperimentering, risiko og toleranse (Ellström, 2012). Ellström peker på utfordringer knyttet til spenningen mellom produksjonslogikken hvor for eksempel fokuset på effektivitet vektlegges mer enn kreativitet og utviklingsprosesser i utviklingslogikken.

\section{Pragmatisk læringsperspektiv på helhetlig yrkesfaglærerkompetanse}

Yrkes- og profesjonsdidaktisk opplæring innebærer at studentene ser hvordan de didaktiske kategoriene læreforutsetning, rammefaktor, læringsmål, innhold, læreprosess og vurdering inngår i en helhet sammen med elevmedvirkning, mening og yrkesrelevans (Hiim \& Hippe, 2001). Kjernen i yrkesdidaktiske prinsipper er analyse av yrkesoppgaver og -utøvelse som utgangspunkt for læreplananalyse og undervisningsplanlegging. Koherens og helhetlig yrkeskompetanse er også en viktig del av prinsippene (Hiim, 2017; Sylte, 2017). Det helhetlige kompetansesynet er forankret i opplæringsloven §1-2 (1998). Yrkesfaglæreren må utvikle kompetanse i å legge til rette for at yrkesutøveren viser evne til å utføre fagarbeid i et yrke og kunne løse sammensatte utfordringer knyttet til de enkelte arbeidsoppgaver eller til yrkesutøvelsen som helhet. Helhetlig lærer- og yrkeskompetanse omfatter dessuten forståelse for hvordan yrket utøves, for dets funksjon i samfunnet, for dets kultur, tradisjon og utvikling (Sylte, 2017).

Det pragmatiske perspektivet på læring bidrar med viktige perspektiver på yrkes- og profesjonsrettet utdanning hvor læring knyttes til handling, erfaring, kommunikasjon og refleksjon over erfaring med yrkesoppgaver (Dewey, 1916; Hiim, 2013). Imidlertid er det et problem at yrkes- og profesjonsutdanningene som for eksempel lærerutdanninger i for liten grad er preget av en slik kunnskaps- og læringsforståelse (Sylte, 2017). Lærerkompetanse innbefatter uforutsigbare engangshendelser preget av hver enkelt students intensjoner, opplevelser og subjektive erfaringer (Stenhouse, 1975). Derfor kan for eksempel pedagogisk teori aldri alene forutsi og gi anvisninger for yrkesfaglærerens praksis. Lærerkompetanse krever praktisk-teoretisk utvikling av en mer helhetlig lærerkompetanse på Dreyfus og Dreyfus (1986) sitt ekspertnivå.

Dreyfus og Dreyfus (1986) sin teori innebærer kompetanseutvikling på fem nivå fra novise til ekspert. Novise handler om at for eksempel lærerstudenten får noen regler for handling. Det 
kan være teoriundervisning om hvordan de skal planlegge og gjennomføre et undervisningsopplegg. Oppgavesituasjonen blir da kontekstfri for de studentene som mangler erfaring som lærer. Dreyfus og Dreyfus (1986) mener studenter først trenger grunnleggende kunnskap knyttet til praksis for etter hvert å trekke inn mer eksempler, case og praktiske $\emptyset$ velser gjennom nivåene viderekommen begynner, kompetanse og dyktighet. Videre utvikler de mer intuitiv ekspertkompetanse basert på teori og praksis. Et viktig mål for YFL er at studentene utvikler yrkesdidaktisk lærerkompetanse for undervisning i brede utdanningsprogram med tidlig yrkesspesialisering. Det fordrer praktisk-teoretisk begrunnelse for innholdet og gjennomføringen av undervisningen, hvorfor resultatene av undervisningen blir som de blir, og hvilke konsekvenser eventuell feil kan gi. Det studenten skal utvikle kan betegnes som en begynnende ekspertkompetanse: «Å utvikle en begynnende ekspertkompetanse handler om å lære seg å lære - om å lære seg nødvendigheten av å bruke skjønn» (Sylte, 2017, s. 85). Dette innebærer utvikling av helhetlig yrkeskompetanse som kan sammenlignes med en begynnende ekspertkompetanse, hvor det brukes både praktiskteoretisk kunnskap og skjønn som innbefatter klokskap og god dømmekraft (Dewey, 1916; Dreyfus \& Dreyfus, 1986).

\section{Lærerkompetansebehov knyttet til norsk yrkesfagopplæring i brede utdanningsprogram}

Kompetansemålene i dagens yrkesopplæring er åpne og generelle med stor grad av tolkningsrom for den enkelte lærer (Kunnskapsdepartementet, 2006, Utdanningsdirektoratet, 2006). Imidlertid er det de åpne kompetansemålene og styringsdokumentene som gir rom for ulik tolkning, som skaper store utfordringer med yrkesretting og yrkesdifferensiering for mange skoler og yrkesfaglærere (Dahlback et al., 2011). I tillegg viser forskning at denne utfordringen henger sammen med lærernes kunnskapssyn og lærerkompetanse, noe vi setter søkelyset på i denne artikkelen (Bødtker-Lund et al., 2017; Sylte, 2017). Samtidig må det også tas hensyn til at det vektlegges tidlig yrkesspesialisering i den nye tilbudsstrukturen (Utdanningsdirektoratet, 2018).

I 2015 kom Yrkesfagløftet, (Utdanningsdirektoratet, 2015) der det ble presisert at alle lærere i tillegg til fagkompetanse må vise formidlingsevne og klasseledelse, og gode relasjoner til elevene. Rapporten sier videre at lærere som underviser i de yrkesfaglige utdanningsløpene 
skal utdanne elever til et yrke og forberede en svært variert elevgruppe til framtidige arbeidstakere. Det pekes på at en viktig del av yrkesfaglærerens kompetanse er ervervet gjennom egen erfaring fra arbeidslivet. Det presiseres også at denne kompetansen må videreutvikles og oppdateres fordi arbeidslivet er i konstant endring og yrkesfaglæreren må ha kjennskap og kontakt med bedrifter for å bidra med praksisplasser og læreplasser (Utdanningsdirektoratet, 2015, s. 6). På bakgrunn av styringsdokument, tidligere forskning og et pragmatisk pedagogisk kunnskapssyn, ser vi dermed behov for en helhetlig yrkesfaglærerkompetanse hvor det vektlegges yrkesrettet og yrkesdifferensiert opplæring i tråd med samfunnets, arbeidslivets og elevenes behov for kompetanse.

\section{Metode}

Forskningen hadde en flermetodisk tilnærming som hovedsakelig innebar kvalitative fenomenologiske forskningsmetoder gjennomført i løpet av fire vårsemestre (2015-2018). For å støtte opp under de kvalitative undersøkelsene om alle deltakende lærerstudenters og praksislæreres erfaringer av kompetansebehov, ble det også gjennomført en spørreundersøkelse som innbefattet elementer fra kvantitativ forskning (Patton, 2015; Postholm, 2005). Forskningsmetodene innebar spørreunders $ø$ kelser, evalueringsskjemaer, intervjuer og dialogkonferanse. Alle forskningsmetodene var knyttet til forskningsspørsmålene som handlet om hvilken lærerkompetanse studentene viste i pedagogisk praksis og hvilken lærerkompetanse det er behov for i brede yrkesfaglige utdanningsprogram med vekt på tidligere yrkesspesialisering.

\section{Empirigrunnlaget}

Informantene var 11 praksislærere og 72 lærerstudenter i pedagogisk praksis på Vg1 i 15 fylker i Norge. Undersøkelse ble gjennomført med 29 studenter i andre studieåret og 43 studenter i tredje studieåret.

I spørreundersøkelsen med studentene ble data innhentet gjennom et digitalt spørreskjema i Survey Monkey. Spørreskjemaet inkluderte både lukkede og åpne spørsmål, slik at informantene også fikk mulighet til å utdype fenomenet kvalitativt (Kvale \& Brinkmann, 2015). 
Intervjuene med praksislærere ble gjennomført på 11 videregående skoler i 8 fylker våren 2015 og våren 2016, i forbindelse med pedagogisk praksisbes $ø \mathrm{k}$. Vi brukte en halvstrukturert intervjuguide (Kvale \& Brinkmann, 2015). Intervjuguiden startet med lukkede spørsmål med graderte svaralternativer der spørsmålene ble etterfulgt av et oppfølgings-spørsmål som ga praksislærerne mulighet til å utdype fenomenet kvalitativt.

Praksislærernes evalueringsskjema av studentenes gjennomføring av pedagogisk praksis i Vg1, dokumenterte vurdering av studentenes oppnådde kompetanse i praksisperioden, basert på YFL-rammeplanens (Kunnskapsdepartementet, 2013) krav til kompetanse inndelt i fem kategorier: Relasjons- og samarbeids kompetanse, faglig kompetanse (dybde og bredde), yrkesdidaktisk kompetanse, utviklings- og endrings kompetanse og yrkesetisk kompetanse.

Det ble også gjennomført dialogkonferanser med studenter på samlingene i vårsemestrene 2016, 2017 og 2018. Studentene jobbet i rullerende grupper med avsatt tid for refleksjon og bearbeidelse av praktiske erfaringer (Eikeland, 2017). Her oppsummerte de sine erfaringer fra egen undervisning på Vg1 DH etter gjennomført pedagogisk praksis. I tillegg innhentet vi data ved en forskningskonferanse høsten 2017. I en workshop under konferansen presenterte vi våre foreløpige funn, der vi også inviterte rundt 30 yrkesfaglærere på Vg1 DH og to skoleledere til innspill og diskusjon for videre utdyping av fenomenet.

Selv om vi har brukt ulike forskningsmetoder, handlet alle metodene om de to forskningsspørsmålene for å belyse hovedproblemstillingen.

\section{Analyse, validitet og etikk}

Vi brukte Excel og HyperResearch som analyseverktøy. Aanalysen tok primært utgangspunkt i prosjektets pragmatiske og yrkesdidaktiske teoretiske perspektiv (Dahlback et al., 2018).

Dataene ble transkribert og sammenfattet ut fra Kvale og Brinkmans (2009) tre analysenivåer; selvforståelse, kritisk forståelse basert på sunn fornuft og pragmatisk teoretisk forståelse. Hovedkategoriene var: Studenters viste kompetanse i pedagogisk praksis og kompetansebehov med tidlig yrkesspesialisering i brede utdanningsprogram. I tillegg analyserte vi resultatene etter fem underkategorier i tråd med kompetansekravene i YFLs rammeplan (Kunnskapsdepartementet, 2013). 
Vi var fire forskere som er tilknyttet yrkesfaglærerstudiet, alle underviste ved studiet og observerte studentene i deres pedagogiske praksis. Vårt pragmatiske pedagogisk- og didaktisk-teoretiske perspektiv på læring påvirket forskernes forståelse av hvilken kompetanse som kreves av en yrkesfaglærer som skal undervise i brede utdanningsprogram.

Forfatternes roller i studien var både som undervisningsansvarlige og forskere. Det kan innebære en forutinntatthet ved analysen og en etisk utfordring som vi var bevisste på. Studentene i rollen som informanter var avhengig av godkjenning og karakterer fra sine faglærere, der denne avhengigheten kunne representere en utfordring for validiteten. Derfor var forskerne bevisste på å være nødvendig distansert i forskerrollen i analyseprosessen (Kvale \& Brinkmann, 2015; Patton, 2015). For å unngå at forskerne var suveren i utvelgelsen av empiriske eksempler, fikk informantene mulighet til å korrekturlese transkripsjonen av intervjuene og bidra til å korrigere forskernes tolkning.

Studien er framlagt Norsk samfunnsvitenskapelig datatjeneste, godkjent (nr. 56259) og implementert etter gjeldende retningslinjer.

\section{Resultat og diskusjon}

Resultatene av analysen presenteres i henhold til de to forskningsspørsmålene, før vi til slutt diskuterer hvilken lærerkompetanse det er behov for i brede yrkesfaglige utdanningsprogram for å få til tidlig yrkesspesialisering.

\section{a) Kompetansen studentene viste i pedagogisk praksis}

Funnene er hentet fra intervju med lærerne, studentenes egenvurdering i spørreunders $\varnothing$ kelsen, samt praksislærernes vurdering av studentene etter pedagogisk praksis. Funnene er analysert på tvers av praksislærernes og studentenes vurderinger.

På en skala fra 1-6, der 1 er lav og 6 er høy kompetanse, vurderte praksislærerne studentenes undervisningskompetanse fra nivå 3 og oppover, noe som samsvarer med studentenes egenvurdering. Ut fra både studentenes og praksislærernes vurderinger, ser studentenes undervisningskompetanse ut til å ligge på Dreyfus og Dreyfus (1986) sitt tredje og opp mot femte nivå, kompetanse, dyktighet og en begynnende ekspertkompetanse. I intervjuene sa praksislærerne at studentene var gode til å planlegge undervisningen, de hadde spennende 
presentasjoner og var gode på problemløsing og kritisk tenkning. Dette indikerer en intuitiv og begynnende ekspertkompetanse, der studentene har lært å anvende pedagogisk og didaktisk teori i den praktiske undervisningen gjennom kritisk tenkning og problemløsning i tråd med Wagners (2008) kompetanseområder.

Praksislærerne vurderte studentenes kompetanse i klasseledelse fra nivå 3 og oppover, men over $70 \%$ av dem vurderte studentenes kompetanse til høy og meget høy (4 - 6). De fleste studentene vurderte også sin kompetanse i klasseledelse som høy, men her var det større variasjonen da studentene brukte hele skalaen fra 1 til og med 6. I intervjuene sa praksislærerne at studentene var reflekterte og bevisste rundt egen lærerrolle, mens studentene etterspurte mer trening i klasseledelse. Vi ser her at studentene anvender relevant teori i den praktiske undervisningen gjennom reflektert og kritisk tenkning på nivået dyktighet og begynnende ekspertkompetanse, i tråd med Dreyfus og Dreyfus (1986). Likevel ønsket studentene mer pedagogisk praksis med mulighet til å "trene mer på klasseledelse" (2015: student 2). Dette kan indikere at noen studenter opplevde å være på et begynnende ekspertkompetansenivå (Dreyfus \& Dreyfus, 1986), mens andre studenter trengte mer praktiske øvelser. Disse studenten viste ikke klokskap og skjønn hvor de intuitivt anvendte teori og praksis i undervisningskonteksten slik Deweys (1916) erfaringslæring viser nødvendigheten av. Den samme tendensen kan også ses i forhold til studentenes relasjons- og samarbeidsegenskaper.

Studentenes relasjons- og samarbeidsegenskaper ble vurdert av praksislærerne til meget høyt, (5-6). Til sammenligning viste studentenes egenvurdering at det var individuelle forskjeller fra student til student, da $10 \%$ vurderte sine samarbeidsegenskaper lavere (4). Jevnt over viste imidlertid både praksislærernes og studentenes tilbakemeldinger at studentene hadde opparbeidet seg en god relasjons- og samarbeidskompetanse. Dette viste at studentene også innenfor dette området hadde utviklet kompetanse som etterspørres i dagens skole og i arbeidslivet for øvrig (Wagner 2008, Word Economic Forum, 2018).

Praksislærerne vurderte studentenes breddekompetanse fra nivå 2 og til og med nivå 6, noe som samsvarer til dels med studentenes egenvurdering. Forskjellen her var at hovedvekten av praksislærerne vurderte studentenes kompetanse til nivå 3, mens mange studenter vurderte egen kompetanse til nivå 4. Samtidig sa svært mange av studentene at de trengte mer 
breddekompetanse for å undervise på $\mathrm{Vg} 1$. De etterlyste mer praktisk arbeid og praktiske øvelser inn i studiet, og de mente de trengte mer kompetanse knyttet både til ungdomsskolen og Vg1. De forsto at de også måtte utvikle breddekompetansen i etterkant av studiet og en student skrev: "Jeg kunne fortsatt hatt mer breddekompetanse, men med så mange fag som ligger under $\mathrm{DH}$, er vel dette et område jeg aldri kan få nok av, og må jobbe videre med i årene framover" (2016: student 8). I breddekompetanse viste studentene langt lavere kompetansenivå i henhold til Dreyfus og Dreyfus (1986). Det kan synes som om breddeoppgavesituasjonen for studentene var til dels kontekstfri ved YFL, og at studentene manglet erfaring som lærere i brede Vg1. Dreyfus og Dreyfus mener studenter først trenger grunnleggende kunnskap knyttet til praksis, noe de har fått ved YFL. Imidlertid kan det virke som at det har vært for lite praktiske eksempler og øvelser i breddeundervisningen ved YFL, siden studentene her ikke intuitiv anvendte teori og praksis i undervisningskonteksten.

Dermed trengte studentene mer læring knyttet til handling og erfaring. Samtidig kommuniserte og reflekterte de over egen erfaring med brede yrkesoppgaver og her viste de at de var bevisste på at de trengte mer praktisk trening og erfaring i breddekompetanse (Dewey, 1916; Hiim, 2013).

I yrkesfaglig dybdekompetanse vurderte mange av praksislærerne studentenes kompetanse høyt og meget høyt (4-6), men studentene vurderte seg selv enda høyere. Under $10 \%$ av studentene og over $50 \%$ av praksislærerne vurderte kompetansen til nivå 4, mens vel $90 \%$ av studentene vurderte seg selv til nivå 5 og 6. Praksislærere mente generelt at det var store variasjoner fra student til student i forhold til deres praktiske ferdigheter i eget yrke. De fleste studentene følte seg imidlertid jevnt over trygge i eget fagområde. Her kan det virke som om studentene ikke har samme innsikt i hvilket nivå dybdekompetansen var i forhold til hva praksislærerne mente den burde være. Praksislærerne vurderte studentenes dybdekompetanse som lærere på Dreyfus og Dreyfus (1986) sine nivåer kompetanse og dyktighet, mens flere studenter opplevde at de var på et begynnende ekspertkompetansenivå, der de intuitivt løste komplekse situasjoner basert på teori og praksis. Samtidig var noen frisørstudenter bevisste på at de manglet kompetanse i enten herre- eller damefrisørfaget, da disse to fagbrevområdene ble slått sammen til frisørfaget i Kunnskapsløftet i 2006. I slike tilfeller hadde de ekspertkompetanse i sitt fag-/svennebrev, men et langt lavere kompetansenivå som lærere i det andre svennebrevområdet, selv om disse var nær beslektet. En student skrev: "Jeg 
har svennebrev som damefrisør, men er ikke dyktig i å klippe herrefrisyrer” (2015: student 2). Den samme tendensen som over, kan ses i yrkesfaglig teori som viser store forskjeller i praksislærernes vurdering av studentenes kompetanse og studentenes egenvurdering av kompetanseområdet. De fleste praksislærerne vurderte her studentenes kompetanse i yrkesfaglig teori mellom lav og middels, mens et fåtall av studentene vurderte egen kompetanse til under middels. Her vurderte de aller fleste studentene egen kompetanse som svært høy.

I intervjuene mente studentene at utviklings- og endringskompetanse var et av kompetanseområde de utviklet på en god måte gjennom utviklingsarbeidene i studiet, men i praksislærernes tilbakemeldinger i vurderingsskjemaene var det store individuelle forskjeller hvor løsningsorienterte de mente studentene var i konkret handling. Praksislærerne opplevde imidlertid de fleste studentene som flinke til å ta imot og videreutvikle egen praksis på bakgrunn av den veiledningen de fikk. Utviklings og endringskompetanse innbefatter problemløsning og kritisk tenkning, som ble fremhevet av både Wagners (2008) og Word Economic Forums (2018) som en av de viktigste kompetansene i framtidens arbeidsliv.

\section{b) Kompetansebehov i brede utdanningsprogram med tidlig}

\section{yrkesspesialisering}

Funnene bygger på resultater fra intervju og forskerkonferanse med praksislærere, spørreundersøkelser og dialogkonferanser med studentene.

Hele $70 \%$ av praksislærerne og vel $60 \%$ av studentene mente det å opparbeide kompetanse i yrkesfaglig bredde var et av de områdene det burde være mer fokus på i studiet. I de kvalitative unders $\varnothing$ kelsene kom det imidlertid fram at det var ulike oppfatninger om hva dette innebar. Studentene mente de trengte mer innsikt i ulike teknikker og utøvelsen av ulike håndverksteknikker, noe de ønsket mer trening i på universitetet og i yrkesfaglig praksis arbeidslivet. Ellströms (2012) forskning viser til nødvendigheten av å ha forståelse for hvert enkelt yrkes produksjons- og utviklingsfaser for å kunne gi opplæring og undervisning på en relevant måte. Begge disse perspektivene er nødvendige for å kunne tilrettelegge for tidlig yrkesspesialisering. 
Nødvendigheten av å videreutvikle nettverket sitt og samarbeide med kompetente yrkesutøvere innenfor andre yrker enn man selv har bakgrunn i, ble fremhevet både av studenter og praksislærere som viktig for å kunne undervise på brede Vg1. Dette blir en mer utvidet forståelse av nettverk og samarbeid enn det Wangers (2008) trekker fram, da det her handler om at yrkesfaglærere og utøvende yrkesutøvere sammen må ta et ansvar for tidlig yrkesspesialisering allerede på Vg1. Både praksislærere og studenter fremhevet at det var umulig å ha innsikt i alle yrkene. Derimot mente de at det var viktig med kunnskap om felleselementene, for å kunne gi et relevant faglig innhold med substans.

Enkelte av praksislærerne mente studentene manglet generell kompetanse innenfor form, farge, tegning, kunst- og kulturhistorie. Dette er temaer som representerer noen av felleselementer yrkene imellom, men som brukes svært ulikt fra yrke til yrke. Studentene bekreftet at dette var noe de trengte mer kompetanse innenfor, men da med utgangspunkt $\mathrm{i}$ hvordan de kan yrkesrette innholdet. Andre praksislærere fremhevet at det viktigste var at studentene opparbeidet kompetanse i alle yrkene de skulle veilede sine elever mot. Spørsmålet i framtidens yrkesopplæring blir dermed, hvordan felleselementene yrkene imellom kan yrkesrettes på en slik måte at det gir tidlig yrkesspesialisering allerede på Vg1. Jørgensen (2018) sier at det å ha opparbeide kompetanse tilpasset et arbeidsliv i stadig endring, er en av de fire største utfordringer i dagens fag- og yrkesopplæring. Dette krever å se yrkene i et samfunnsperspektiv, der innovasjon, utviklings- og endringskompetanse er sentrale elementer i kompetanseutviklingen. Likevel sa kun cirka $40 \%$ av studentene og $20 \%$ av praksislærerne at det burde være mer fokus på yrkesfaglig dybde. Noen av praksisveilederne poengterte at enkeltstudenter trengte mer yrkesfaglig teoretisk dybde, mens de fleste var enig $\mathrm{i}$ at studentene hadde den nødvendige kunnskapen de trengte til å undervise på dette nivået. Kan dette bety at dagens lærere og studentene ikke ser behov for å videreutvikle egen fagkompetanse opp mot framtidens behov for kompetanse, eller handler dette om at de ikke klarer å se fagkompetanse opp mot nøkkelkompetansene man trenger for å opparbeide helhetlig yrkeskompetanse? Samfunnsperspektivet er vektlagt i Dreyfus og Dreyfus (1986) sitt ekspertnivå, der yrkesoppgaven og -utøvelsen må sees opp mot samfunnsutviklingen og -mandatet yrket innebærer. Det innebærer også å lære seg å lære, dermed krever helhetlig yrkeskompetanse livslang læring (Billett, 2014). 
I noen yrker ble det henvist til stor teknologisk utvikling, som gjorde at både studenter og praksislærere sa de trengte oppdatering. Dette gjaldt spesielt innenfor trearbeid, interiør- og utstillingsdesign, medieproduksjon og enkelte av design- og tekstilfagene. Kompetanse i ny teknologi vil dermed være påkrevet for å kunne gi tidlig yrkesspesialisering på Vg1, i tillegg til innsikt i de manuelle teknikkene, finmotorikk og håndlag (Deichman-Sørensen, 2015; Sennet, 2016).

$40 \%$ av praksislærerne og under $40 \%$ av studentene framhevet behovet for mer pedagogikk, mens hele $60 \%$ av praksislærerne og vel $40 \%$ av studentene så behov for mer yrkesdidaktikk. Studentene $\emptyset$ nsket seg flere praktiske eksempler og øvelser i hvordan de skal tilrettelegge opplæring for elever med ulike yrkesbehov. De forsto tenkningen bak tidlig yrkesspesialisering på $\mathrm{Vg} 1$, men forsto ikke alltid hvordan de skulle kunne gjennomføre opplæringen i praksis. Ikke alle følte seg forberedt i møte med elevenes ulike behov. Samtidig peker forskning i likhet med våre funn, på at det er av stor betydning at yrkesfaglærere har yrkesdidaktisk kompetanse, og har innsikt i de ulike yrkenes arbeidsprosesser for å tilrettelegge for yrkesrelevant opplæring på brede Vg1 (Bødtker-Lund et al., 2017; Hiim 2013). Det innebærer at opplæringen blir yrkesrettet og forankret i yrkenes behov for kompetanse (Dahlback et al., 2011).

Det mange studenter og praksislærere uttrykte som krevende i dagens skole var hvordan man skulle møte elever som manglet engasjement og motivasjon for læring. Ikke alle elever kom inn på sitt førstevalg, og mange slet med sosial angst, skrive- og lesevansker, generelle lærevansker og rus, for å nevne noe. De nevnte også utfordringer med elever som ikke kunne snakke og skrive norsk. Flerkulturelle klasser og økende antall elever med minoritetsbakgrunn krevde innsikt i ulike kulturer, og metodiske grep som sikret at elevene klarte å følge opplæringen og følte seg integrert. Jørgensen (2018), bekrefter at sosial integrering er en av fire utfordringer i dagens fag- og yrkesopplæring. Dette har ikke direkte innvirkning på hvilken kompetanse en lærer trenger for å undervise på brede utdanningsprogram med tidlig yrkesspesialisering, men kan være en mulig forklaring på at mange yrkesfaglærere og studenter føler at de kommer til kort, hvis de ikke har kompetanse til å møte disse utfordringene. 


\section{Hvilken kompetanse er det behov for i brede yrkesfaglige utdanningsprogram?}

Våre funn viser at yrkesfaglærere bør utvikle en dypere forståelse av yrkenes egenart, for å kunne begrunne og vurdere hva elevene trenger å lære opp mot bransjenes og samfunnets stadig endrede behov. Det gjenspeilet seg spesielt når studentene underviste i brede utdanningsprogram. Utfordringen var at studentene mente de hadde utviklet en begynnende ekspertkompetanse innen eget fagbrevområde, mens i breddefagene var de mer på Dreyfus og Dreyfus (1986) sitt viderekommen begynner - dyktighets-nivå. Et betimelig spørsmål blir da om det er realistisk at studenter kan oppnå høyere kompetanse enn viderekommen begynner og dyktighet i de ulike yrkene Vg1 leder til.

Studentene klarte å gi eksempler og legge til rette for enkle praktiske øvelser, mens de viste lavere kompetanse når det kom til en mer dypere forståelse av yrkenes egenart. Samtidig kan det diskuteres om det er mer realistisk at studentene utvikler høyere fagkompetanse innen breddefagene senere i sin lærerpraksis, slik en av studentene mente de måtte, altså lære seg å lære. Lærer $\neg$ kompetanse innebærer at lærere ikke bare vet hva som skal gjøres, de vet også hvordan. Det krever et stort handlingsrepertoar relatert til å kunne skjelne mellom ulike situasjoner på ekspertnivå (Dreyfus \& Dreyfus, 1986). På det kompetansenivået vil ikke lærerstudentene lengre være bundet opp av reglene for praksis, men vet hvordan den adekvate handlingen foretas uten å beregne eller sammenlikne alternativer. Våre studenter viste til dels helhetlig yrkeskompetanse gjennom koherens mellom universitetet og deres pedagogiske praksis innen alle kompetanseområdene med unntak av breddekompetanse. Dermed kan vi spørre, hvor de subtile skillene går mellom hva som er forsvarlig når studentene skal undervise i fagenes egenart, versus å legge til rette for at elever lærer seg arbeidsprosesser gjennom samarbeid med arbeidslivet.

Studentene etterspurte mer praksis i både skole og arbeidsliv, men ønsket også mer praktisk og fysisk jobbing på universitetet, for å kunne lære nye teknikker med mulighet til å prøve gjennom erfaringslæring. Man trenger kunnskap og ferdigheter til å gjøre jobben, men også kompetanse til å være uavhengig og i stand til å evaluere og utvikle arbeidet (Dewey, 1916). Samfunnet er preget av et arbeidsliv i stadig endring, med høy grad av kompleksitet, og nye kunnskapsområder (Kunnskapsdepartementet, 2016, Sennet, 2008). Utvikling av ny 
teknologi, bruk av datamaskiner, sosiale medier etc., krever ny innsikt og fleksibilitet. I tillegg til dette krever mange av DH-yrkene innsikt i spesifikke håndverksteknikker. Hvis opplæringen blir så generell at den kun skal tilfredsstille endringsbehovene i samfunnet, kan de spesifikke ferdighetene og teknikkene du trenger for å kunne utøve spesifikke yrker bli borte (Deichman-Sørensen, 2015; Sennet, 2008). Fleksibilitet er nødvendig for de fleste yrker i dag, men vi må forsøke å unngå at det blir en overfladisk kunnskap og et arbeidsliv uten substans (Sennet, 2008). Våre funn viser at både praksislærere og studenter etterlyste mer opplæring i tekniske ferdigheter i bredde, for å kunne gi et faglig innhold med mer tyngde. Spørsmålet blir da hvor den etiske grensen går for hva våre studenter skal kunne gi opplæring i innenfor andre yrkers produksjons- og utviklingsprosesser utover sitt eget fagbrevområde, slik Engström (2012) ser nødvendigheten av.

For å kunne gi yrkesrelevant opplæring utover sitt eget fagbrevområde mente både praksislærerne og studentene at yrkesfaglærere var helt avhengig av å videreutvikle sitt nettverk og samarbeid med arbeidslivet. Dette gjelder spesielt innenfor de små fagene som urmaker, børsemaker osv. der det ikke vil være nok elever til å gi tidlig yrkesspesialisering på skolen. Hiims $(2013,2015)$ forskning peker mot at samarbeid med arbeidslivet og elevenes muligheter for arbeidslivserfaring i yrker de er interesserte $\mathrm{i}$, har stor betydning for deres yrkesfaglige læring. En kjerne i breddekompetansen hos yrkesfaglærere er evne til samarbeid med arbeidslivet, nettopp fordi det ikke er mulig for lærerne å ha ekspertkompetanse i alle yrkenes produksjons- og utviklingsfaser. Resultatene viser også at de timene elevene har i yrkesfaglig fordypning, ikke vil dekke behovet disse elevene har for tidlig yrkesspesialisering. Det vil også være nødvendig å bruke programfagstimer i samarbeid med arbeidslivet.

Resultatene synliggjør at studenter har opparbeidet kompetanse i alle de syv kompetanseområdene til Wagner (2008), i tråd med det nye kompetansebegrepet (Kunnskapsdepartementet, 2016). Studentene viste også nysgjerrighet og kreativitet noe som kan bety at studentene har opparbeidet mye av den kompetansen som etterspørres generelt $\mathrm{i}$ arbeidsmarkedet i tråd med det Word Economic Forum (2018) vektlegger. Dette kan ses i sammenheng med at studentene har utviklet en begynnende ekspertkompetanse innen kompetanseområdene relasjons- og samarbeidskompetanse, og til dels i faglig dybdekompetanse, pedagogisk- og yrkesdidaktisk kompetanse, utviklings- og endrings- 
kompetanse og yrkesetisk kompetanse (Dreyfus \& Dryfus, 1986; Sylte, 2017). Samtidig viser resultatene at selv om studentene har utviklet kompetanse i å lære seg å lære, vil det fremdeles fortsatt være stort behov for å utvikle kompetanse i yrkesdifferensiering i tråd med Bødtker-Lunds et al. (2017) forskning. Resultatene peker med andre ord på at tidlig yrkesspesialisering krever innsikt i yrkene, samarbeid på tvers av lærere og skoler, og et godt nettverk med arbeidslivet.

\section{Yrkesfaglærerutdanningens utdanningsinnhold i lys av ny tilbudsstruktur i videregående opplæring 2020}

Med ny struktur i videregående opplæring vil det bli nødvendig å tilpasse programplanene for YFL til det nye innholdet i yrkesopplæringen (Utdanningsdirektoratet, 2017, 2018). I Meld. St. 28 (Kunnskapsdepartementet, 2016) og i NOU (2015: 8) oppfordres det til at elvene skal få mulighet til dybdelæring gjennom yrkesspesialisering. Samtidig vektlegges det i den overordnede delen - verdier og prinsipper i opplæringen (Utdanningsdirektoratet, 2017), at bærekraft, folkehelse, livsmestring, og demokrati skal integreres som tverrfaglige temaer i alle fag.

Samfunnet er i endring, samtidig som vi må ivareta fagenes særpreg og tradisjoner (Sennet, 2008). På bakgrunn av resultatene ser vi behov for å få et spisset innhold i YFL som grunnlag for mer dybdelæring og yrkesspesialisering i tråd med arbeidslivets og samfunnets behov for kompetanse, og å styrke koherensen mellom profesjonsfaget og praksisfeltet ytterligere (Canrinus et al., 2015; Heggen \& Terum, 2013; Hiim, 2015; Sylte, 2018).

Resultatene våre viser at både yrkesfaglærerne og studentene trenger mer faglig substans i sin breddekompetanse, for å kunne tilrettelegge for tidlig yrkesspesialisering. Til tross for at det $\mathrm{i}$ den nye strukturen er vedtatt færre fag innenfor det som i dag er Vg1 DH (Utdanningsdirektoratet, 2018), vil det fremdeles være mange yrker en yrkesfaglærer skal ha kompetanse og innsikt i. Det store spørsmålet vi må ta stilling til er derfor hvor høy kompetanse yrkesfaglærerne trenger i bredde for å kunne gi god dybdelæring og tidlig yrkesspesialisering. 
Et betimelig spørsmål vil være om det er økonomi til utstyr og verksteder for praktiske $\emptyset$ velser på universitetet slik studentene etterspurte. Som en av studentene sa: «(...) med så mange fag som ligger under DH, er vel dette et område jeg aldri kan få nok av, og må jobbe videre med i årene framover (...)». Et annet spørsmål er hvilket breddekompetansenivå studentene trenger å lære gjennom YFL, og hva de må lære seg å lære gjennom videreutvikling i etterkant av studiet gjennom variert arbeidspraksis i tråd med tenkningen til Billett (2014), Dreyfus og Dreyfus (1986) og Ellström (2012).

Resultatene peker også på at det er et økende antall elever med sosiale- og særskilte behov på Vg1. Dermed trenger også YFL-studenter å tilrettelegge for særskilte behov i undervisningen. Jørgensen (2018) trekker også fram det å inkludere elever som ikke er modne for videregående opplæring som en av de store utfordringene i yrkesopplæringen i Norden. Spørsmålet blir da hva en YFL bør inneholde, og hva som eventuelt må være videreutdanning innenfor det mer sosial- og spesialpedagogiske feltet.

\section{Oppsummering og veien videre}

Endringene i den nye tilbudsstrukturen vi gi implikasjoner for innholdet i YFL. I noen av utdanningsprogrammene blir det få endringer, mens $\mathrm{Vg} 1 \mathrm{DH}$ blir delt i to nye utdanningsprogrammer (Utdanningsdirektoratet, 2018). Begge løpene vil fremdeles inneholde yrker med svært ulike arbeidsprosesser og materialer med behov for ulikt faglig innhold. For å gjennomføre den nye tilbudsstruktur med vekt på tidlig yrkesspesialisering og relevansproblematikken ser vi at yrkesfaglærere i tillegg til kompetansene innen pedagogikk og yrkesdidaktikk, må ha bredde- og dybdekompetanse i alle yrkene som inngår i utdanningsprogrammet. Innholdet i YFL må spisses og gi grunnlag for mer dybdelæring i tråd med arbeidslivets- og samfunnets behov for kompetanse. For å oppnå dette kreves det nettverk av yrkesutøvere og bedrifter yrkesfaglærere kan samarbeide med, for å gi relevant opplæring i de yrkene de selv ikke har fag- eller svennebrev. Dermed ser vi behov for etterog videreutdanningstilbud for yrkesfaglærere i hvordan yrkesspesialisering bør gjennomføres i brede utdanningsprogram.

For yrkesfaglærere er det nødvendig å ha kompetanse i å analysere de generelle og brede læreplanene opp mot de faktiske behovene i samfunnet, arbeidslivet og til hver enkelt elevs 
yrkesinteresser og utdanningsplaner. Det er derfor behov for å styrke den faglige substansen i felleselementene i de ulike yrkene som inngår i programområdet. Uten denne yrkesdifferensierte- og yrkesdidaktiske kompetansen viser funnene at det ikke er mulig å gi en yrkesrelevant opplæring. Det bør derfor være et krav at lærere som skal undervise på brede Vg1 har et fag- eller svennebrev, og yrkeserfaring fra ett eller flere av yrkene som inngår i utdanningsprogrammet.

\section{Referanser}

Aspøy, T., Skinnarland S. \& Tønder A. H. (2017). Yrkesfaglærerens kompetanse. Faforapport 2017:11. Oslo: Fafo. https://www.fafo.no/images/pub/2017/20619.pdf

Bødtker-Lund, D., Hansen, K. H., Haaland, G. \& Vagle, I. (2017). Endringsbehov i norsk yrkesopplæring? - Elevers, lærlinger og yrkesfaglærers erfaringer med yrkesopplæring i Vg1. Scandinavian Journal of Vocations in development, (2), 1-33. http://dx.doi.org/10.7577/sjvd.2577

Billett, S. (2014). The standing of vocational education: sources of its societal esteem and implications for its enactment. Journal of Vocational Education \& Training, 66(1), 121. DOI: http://dx.doi.org/10.1080/13636820.2013.867525

Canrinus, E. T., Bergem, O. K., Klette, K. \& Hammerness, K. (2015). Coherent teacher education programmes: Taking a student perspective. Journal of Curriculum Studies, 49(3). DOI: http://dx.doi.org/10.1080/00220272.2015.1124145

Dahl, T., Bruland, S., Morland, S. \& Aaslid, B. E. (2012). På de samme stier som før Kunnskapsløftet i fag- og yrkesopplæringen. Trondheim: SINTEF. https://www.udir.no/globalassets/filer/tall-og-forskning/rapporter/2012/pa-sammestier.pdf

Dahlback, J., Hansen, K., Haaland, G. \& Sylte, A. L. (2011). Yrkesdidaktisk kunnskapsutvikling og implementering av nye læreplaner (KIP) - Veien til yrkesrelevant opplæring fra første dag i Vg1. Oslo: Høyskolen i Oslo og Akershus. https://fagarkivet.oslomet.no/nb/item/yrkesdidaktisk-kunnskapsutvikling-ogimplementering-av-nye-laereplaner-kip-veien-til-yrkesrelevant-opplaering-fra-forstedag-i-vg1 
Dahlback, J., Hansen, K., Haaland, G. \& Vagle, I. (2015). Yrkesfaglærerens kompetanse i fremtidens skole. I K. H. Hansen, T. L. Hoel \& G. Haaland (red.), Tett på yrkesopplæring. Yrkesrelevant, tilpasset og samfunnstjenelig? (s. 19 - 46). Bergen: Fagbokforlaget.

Dahlback, J., Haaland, G. \& I. Vagle (2016). Arbeidsplassbasert treårig yrkesfaglærerutdanning (ABY). HiOA rapport 2016 nr. 1. Kjeller: Høgskolen i Oslo og Akershus.

Dahlback, J., Olstad, H. B., Sylte, A. L. \& Wolden, A-C. (2018). Utfordringer og muligheter i møtepunktet mellom yrkesfaglærerutdanningen og praksis i videregående skole. Nordic Journal of Vocational Education and Training, 8(3), 57-77. http://dx.doi.org/10.3384/njvet.2242-458X.188357

Deichman-Sørensen, T. (2015). «Lik kvalitet» - fra yrkesstyring til ytrestyring, fra praksisfellesskap til fellesmarked. Fremveksten av en ny kvalitetsøkonomi i fag- og yrkesopplæringen. I O. Eikeland, H. Hiim \& E. Schwencke (Red), Yrkespedagogiske perspektiver, (s. 140-167). Oslo: Gyldendal Akademisk.

Dewey, J. (1916). Democracy and Education: An introduction to the philosophy of education. New York: Macmillan.

Dreyfus, H. L. \& Dreyfus, S. E. (1986). Mind over Machine: The Power of human intuition and expertice in the era of the computer. New York: Free press.

Eikeland, O. (2017). Aristotelisk aksjonsforskning. I S. Gjøtterud, H. Hiim, D. Husebø, L. H. Jensen, T. H. Steen-Osen \& E. Stjernstrøm (red.). Aksjonsforskning i Norge: Teoretisk og empirisk mangfold (s. 133-164). Oslo: Cappelen Damm Akademisk.

Ellström, P. E. (2012). Læring i spændingsfeltet mellem produktionens og udvilingens logic. I K. Illeris (Red.), 49 tekster om læring (s. 467 - 476). Fredriksberg: Samfunnslitteratur.

Hansen, K. \& Haaland, G. (2015). Utfordringer i norsk yrkesopplæring. I K. H. Hansen, T. L. Hoel \& G. Haaland (red.): Tett på yrkesopplæring (s.19-46). Bergen: Fagbokforlaget.

Heggen, K. \& Terum, L. I. (2013). Coherence in professional education: Does it foster dedication and identification? Teaching in Higher Education, 18(6), 656-669. DOI: http://dx.doi.org/10.1080/13562517.2013.774352 
Hiim, H. (2013). Praksisbasert yrkesutdanning. Hvordan utvikle relevant yrkesutdanning for elever og arbeidsliv? Oslo: Gyldendal akademisk.

Hiim, H. (2015). Kvalitet i yrkesutdanningen: Resultater fra et aksjonsforskningsprosjekt om yrkesforankring av innholdet i yrkesutdanningen. Norsk pedagogisk tidsskrift, 99(2), 136-148. https://www.idunn.no/npt/2015/02/kvalitet_i_yrkesutdanningen__resultater_fra_et_aksjonsfors

Hiim, H. (2017). Ensuring Curriculum Relevance in Vocational Education and Training: Epistemological Perspectives in a Curriculum Research Project aimed at Improving the Relevance of the Norwegian VET. International Journal for Research in Vocational Education and Training, 4(1), 1-19 DOI https://doi.org/10.13152/IJRVET.4.1.1

Hiim, H. \& Hippe, E. (2001). Å utdanne profesjonelle yrkesutøvere. Oslo: Gyldendal. Høgskolen i Oslo og Akershus (2014). Programplan Bachelorstudium yrkesfaglærerutdanning design og håndverk. Kjeller: Høgskolen i Oslo og Akershus.

Høst, H., Reegård, K., Reiling, R. B., Skålholt, A., Tønder, A. H. (2015). Yrkesutdanninger med svak forankring i arbeidslivet: En kunnskapsoppsummering. NIFU-rapport 2015:16. Oslo: NIFU. https://brage.bibsys.no/xmlui/bitstream/handle/11250/284094/NIFUrapport201516.pdf? sequence $=1 \&$ isAllowed $=\mathrm{y}$

Jørgensen, H. J. (2018). Vocational education and training in the Nordic countries. Different systems and common challenges. I Jørgensen, C. H, Olsen, O. J \& Thunquist, D. P (2018). Vocational education in the nordic countries. Learning form diversity (s. 128). London \& New York: Routledge.

Kunnskapsdepartementet (2006). Læreplanverket Kunnskapsløftet (LK -06). Oslo: Kunnskapsdepartementet.

Kunnskapsdepartementet (2009). Læreren - rollen og utdanningen (St.meld. nr. 11 (20082009)). Oslo: Departementet. https://www.regjeringen.no/contentassets/dce0159e067d445aacc82c55e364ce83/no/p dfs/stm200820090011000dddpdfs.pdf 
Kunnskapsdepartementet (2013). Forskrift om rammeplan for yrkesfaglærerutdanning for trinn 8-13. Oslo: Kunnskapsdepartementet. https://www.regjeringen.no/globalassets/upload/kd/vedlegg/rammeplanen/yrkesfaglae rerutdanning.pdf

Kunnskapsdepartementet (2013). På rett vei. Kvalitet og mangfold i fellesskolen (Meld. St. 20 (2012-2013)). Oslo: Departementet. https://www.regjeringen.no/contentassets/53bb6e5685704455b06fdd289212d108/no/ pdfs/stm201220130020000dddpdfs.pdf

Kunnskapsdepartementet (2017). Lærerutdanning 2025. Nasjonal strategi for kvalitet og samarbeid i lærerutdanningene. Oslo: Kunnskapsdepartementet. https://www.regjeringen.no/contentassets/d0c1da83bce94e2da21d5f631bbae817/kd_n asjonal-strategi-for-larerutdanningene_nett.pdf

Kvale, S. \& Brinkmann, S. (2015). Det kvalitative forskningsintervju (2. utg). Oslo: Gyldendal akademisk.

Landro, J. \& Utvær, S. B. K. (2010). Framtidig avgang og nåværende kvalifiseringsbehov blant yrkesfaglærere i Sør-Trøndelag. NTNU: Program for lærerutdanning.

McNiff, J. (2002). Action Research. Principles and Practice. London: Routledge Falmer.

NOU 2015: 8. (2015). Fremtidens skole. Hentet fra: https://www.regjeringen.no/no/dokumenter/nou-2015-8/id2417001/

Opplæringslova (1998). Lov om grunnskolen og den vidaregåande opplæringa (LOV-199807-17-61). Hentet fra https://lovdata.no/lov/1998-07-17-61

Patton, M. Q. (2015). Qualitative Research \& Evalutation Methods. California: SAGE Publicatons.

Postholm, M. B. (2005). Kvalitativ metode: en innføring med fokus på fenomenologisk, etnografisk og kasusstudier. Oslo: Universitetsforlaget.

Sennet, R. (2008). The Craftsman. London: Penguin Books.

Skulberg, H. \& Sund, A. K. M. (2011) Dusinet fullt - tolv grep for en framtidig yrkesfaglærerutdanning. Rapport 1/2011. Oslo: Utdanningsforbundet. 
https://www.utdanningsforbundet.no/globalassets/varpolitikk/publikasjoner/rapporterutredninger/rapport_2011_1.pdf

Stenhouse, L. (1975). An introduction to curriculum research and development. Oxford: Heinemann.

Sylte, A. L. (2014). Vurdering for yrkesrelevant opplæring. Nordic Journal of Vocational Education and Training, 4(1), 1-18. https://doi.org/10.3384/njvet.2242$\underline{458 X .14 v 4 i 1 a 4}$

Sylte, A. L. (2017). Didaktiske prinsipper for relevant yrkes- og profesjonsutdanning. HiOA Avhandlinger 2017 nr. 11. Oslo: Høgskolen i Oslo og Akershus. https://oda.hioa.no/en/item/asset/dspace:25132/A-17-11-Sylte-red.pdf

Sylte, A. L. (2018). Profesjonsretting og studentaktivitet. Scandinavian Journal of Vocations in development, (3), 1-26. DOI: https://doi.org/10.7577/sjvd.2694

Utdanningsdirektoratet (2006). Læreplan i felles programfag i Vg1 design og håndverk. Oslo: Utdanningsdirektoratet.

Utdanningsdirektoratet (2015). Yrkesfagløftet - for framtidig fagarbeidere. Oslo: Utdanningsdirektoratet.

Utdanningsdirektoratet (2016). Forskrift om yrkesfaglig fordypning. Oslo: Utdanningsdirektoratet.

Utdanningsdirektoratet (2017, 17. november). Høring av endringer i den yrkesfaglige tilbudsstrukturen. Hentet fra: https://hoering.udir.no/Uttalelse/63c5fd33-8662-467c$\underline{8545-6633 c 5107 b 51 \text { ?disableTutorialOverlay=true }}$

Utdanningsdirektoratet (2018, 11. mars). Ny tilbudsstruktur og nye læreplaner på yrkesfag. Hentet fra: https://www.udir.no/laring-og-trivsel/lareplanverket/under-arbeid/nytilbudsstruktur-og-nye-lareplaner-pa-yrkesfag/

Vibe, N., Frøseth, M. W., Hovdhaugen, E. \& Markussen, E. (2012). Strukturer og konjukturer: Evaluering av Kunnskapsløftet. Sluttrapport fra prosjektet «Tilbudsstruktur, gjennomføring og kompetanseoppnåelse». Oslo: NIFU. 
Wagner, T. (2008). The Global Achievement Gap: Why Even Our Best Schools Don't Teach the New Survival Skills Our Children Need - And What We Can do About it. New York: Basic Books.

Wheelahan, L. \& Moodie, G. (2010). The quality of teaching in VET: Final Report and Recommendations. Melbourne: Australian College of Educators \& RMIT University. https://melbournecshe.unimelb.edu.au/_data/assets/pdf_file/0008/2554973/quality_vetteaching_final_r eport1.pdf

Word Economic Forum (2018). The Future of Jobs Report 2018. Geneva: Word Economic Forum. http://www3.weforum.org/docs/WEF_Future_of_Jobs_2018.pdf

\section{Om forfatterne}

Jorunn Dahlback er førstelektor ved OsloMet - storbyuniversitetet, Fakultet for lærerutdanning og internasjonale studier. Hun har lang erfaring med undervisning og veiledning ved bachelorutdanningen yrkesfaglærer i design og håndverk, arbeidsplassbasert yrkesfaglærerutdanning og yrkesfaglærerløftet. Hennes forskningsinteresser er yrkesrelevant, kompetanse- og praksisbasert opplæring, vurdering og realkompetansevurdering. Hun har mange års erfaring med forskning innenfor fag- og yrkesopplæring, er opptatt av nettverksbygging og samarbeid universitet, skole og arbeidsliv. Hun har i tillegg bakgrunn som blomsterdekoratør.

Hanne Berg Olstad er universitetslektor ved OsloMet - storbyuniversitet, Fakultet for lærerutdanning og internasjonale studier. Hun underviser ved bachelorutdanningen yrkesfaglærer i design og håndverk. Hennes forskning og utviklingsarbeid er knyttet til samarbeid universitet, skole og arbeidsliv, med fokus på organisering og innhold i opplæringen. Hun har i tillegg bakgrunn som frisør.

Ann Lisa Sylte er førsteamanuensis med doktorgrad ved OsloMet - storbyuniversitet, Fakultet for lærerutdanning og internasjonale studier. Hun har lang erfaring fra undervisning og veiledning ved universitets- og høgskolepedagogikk, yrkesfaglærerutdanning, master i yrkespedagogikk og Ph.d-kurs, samt forskningsarbeid og forskningsgruppeledelse. Hennes forskningsarbeid har fokus på relevant yrkes- og profesjonsutdanning som f.eks. didaktiske prinsipper for yrkes- og profesjonsretting av innhold, arbeidsmåter og vurdering, samarbeid 
universitet, skole og arbeidsliv, samt utvikling av lærerutdanningsskoler. Hun har i tillegg bakgrunn som frisør.

Anne-Catrine Wolden er universitetslektor ved OsloMet - storbyuniversitet, Fakultet for lærerutdanning og internasjonale studier. Hun underviser ved bachelorutdanningen yrkesfaglærer i design og håndverk. Hennes forskning og utviklingsarbeid er knyttet til utvikling av relevant yrkesfaglærerutdanningen, samarbeid universitet, skole og arbeidsliv, profesjonsfaglige digitale kompetanse og videreutvikling av læringsaktiviteter innen yrkesog profesjonsutdanning. Hun har i tillegg bakgrunn som utstillingsdesigner. 